Session

\title{
Sustainability of an Outcome Based Assessment Process: Analysis of the Resource Impact
}

\author{
Marie Dillon Dahleh \\ Department of Mechanical and Environmental Engineering \\ University of California, Santa Barbara \\ Santa Barbara, CA 93106
}

\begin{abstract}
All ABET accredited programs are developing assessment plans, which are used to determine if a program is successfully achieving the program outcomes. These outcomes must include but are not limited to Criterion 3 (a)-(k) of EC 2000. The assessment plans must balance the desire to measure all of the outcomes all of the time and the limited resources available. Most programs plan to mange and maintain this process internally with no new resources allocated. The two major limiting resources are faculty and staff time. This paper provides a detailed analysis of the time required by the faculty and staff to sustain the assessment process for the outcomes and objectives of the Mechanical Engineering department at UCSB. The analysis can be adapted to any assessment plan that relies heavily on surveys.
\end{abstract}

The Mechanical Engineering (ME) program at UCSB has developed an assessment process to evaluate the program objectives and outcomes. Objectives are attributes, which the students should demonstrate within five years of graduation. The ME program has four objectives. The outcomes are skills, which the students should possess at the time of graduation. There are eight outcomes that include all of the required outcomes as specified in Criterion 3 (a)-(k) of EC 2000.

Both objectives and outcomes need to be assessed on a continuous basis. The department has chosen three main methods for assessment. The first method checks which outcomes are met in individual courses. The second method is surveys. These are given to different constituents at various times. The third is focus groups. One is held with the department Industrial Advisor Board ( IAB) and the other is conducted with the current students.

This paper summarizes the assessment process for the ME program at UCSB and describes the impact on both faculty and staff time. The assessment instruments will be briefly described. Followed by a discussion of the work involved in administering and interpreting this instrument. The primary focus of this paper is to determine the sustainability of this assessment process.

Proceedings of the 2002 American Society for Engineering Education Annual Conference \& Exposition Copyright (C)2002, American Society for Engineering Education 
Therefore, the initial work in creating the survey instruments and developing and implementing the process will not be discussed. What will be discussed is the work required to keep the process going between ABET visits.

\section{Assessment instruments}

The ME program in collaboration with the College of Engineering at UCSB has created seven survey instruments. One of these, the course report, is administered quarterly. Two of them, the senior exit survey and the summer survey, are administered once a year. The one-year alumni survey is given every other year and the three to five year alumni survey is distributed every three years. The number of times the employer survey is administered differs from year to year.

Course reports

The Mechanical engineering program consists of six required lower division courses, sixteen required upper division courses and six upper division, along with the basic courses in math, physics, chemistry and the general education. These courses have to provide a student with the skills consistent with the department outcomes. In preparation for the ME program accreditation visit, the faculty submitted course syllabi for all ME courses to the ABET committee. One of the items on the syllabi is course outcomes. The contribution of each course to the program outcomes was determined from these syllabi.

The course report was instituted as a way to monitor how well a course is meeting its outcomes as specified on the syllabus. A staff member distributes a survey to the students at the end of the course, which asks the students to rate how well the course met the outcomes using a five point Lickert scale. The instructor takes these surveys and records the averages for the individual outcomes as part of the report. The instructor also includes the topics covered which may differ from the department syllabus, any laboratory projects, design experience, oral or written communication projects and any social or ethical issues discussed in the course. The curriculum committee, to determine if the department syllabus needs to be changed, reviews the course reports annually.

\section{Senior Exit survey}

All graduating seniors are asked to fill out a survey just before graduation in the spring. This survey is quite detailed consisting of 23 questions many with multiple parts. Several questions specifically ask the students to give an opinion about how well the department met the ME program outcomes. The rest of the questions were included to correspond to questions on the one-year alumni survey and will be used for planning purposes.

The survey is administered through a web-based form. This allows the department to notify all graduating seniors to take the survey with a single e-mail. The results of the survey are processed electronically and sent back to a staff member. The survey results are reviewed annually by the department ABET committee and included in the annual ABET report to the faculty.

Proceedings of the 2002 American Society for Engineering Education Annual Conference \& Exposition Copyright $\odot 2002$, American Society for Engineering Education 
Graduation pass survey

In order for a student to receive the pass to attend graduation he or she must fill out this survey. It asks the students about any job offers, which they have received, and any plans to attend graduate school.

Summer survey

This survey is given to all ME juniors and seniors in the first week of the fall quarter. The intention of this survey is to determine how the students used their time in the summer. This survey is one page consisting of three questions. It is administered by the faculty and is distributed in ME151A, which is required for the junior class, and ME156A, which is required for the senior class. These surveys are reviewed annually by the ABET committee and the results are included in the annual report to the faculty.

One-year alumni survey

This is a very detailed survey containing 45 questions many with multiple parts, which is sent every other year by the office of budget and planning to alumni who graduated one year previous. It is returned to the office of budget and planning for processing. They send a report to the College of Engineering that gives statistics for the engineering alumni. This report is reviewed annually and included in the ABET report to the faculty.

Three to five year alumni survey

This instrument is sent to all ME alumni who have graduate within the last three to five years. The survey contains 17 questions many with multiple parts. It is sent by the ME department and returned to them. The results are reviewed and included in the annual ABET report to the faculty.

\section{Employer survey}

This survey is given to employers of UCSB undergraduates. It is distributed at the annual College of Engineering career fair in the fall quarter and the annual SWE evening with industry in the winter quarter. The career placement office gives it to on campus recruiters. The College office sorts the forms by department and sends them to the department to be processed. The surveys are reviewed annually and the results are included in the ABET report to the faculty.

The survey consists of a single page with six questions. It asks for feedback on all of the technical outcomes of the program.

Necessary resources for the assessment process

The College of Engineering at UCSB hopes to maintain the assessment of the program outcomes and objectives with the current faculty and staff resources. What follows is an estimate of the impact of all of the assessment instruments discussed above on staff and faculty time.

Staff time

Office staff is primarily responsible for preparing the surveys for distribution and collecting them.

Proceedings of the 2002 American Society for Engineering Education Annual Conference \& Exposition Copyright $\odot 2002$, American Society for Engineering Education 
Course reports

The course reports require the students to fill out an outcome evaluation at the end of the course. Since these are specific to each course the office staff needs to prepare a different one for each course taught. There are between 15 and 20 undergraduate courses taught a quarter. Initially the creation of the outcome evaluation for each course is time consuming. Since a course's outcomes should not be changing dramatically from year to year, once the forms have been created, the bulk of the work will be printing and copying them for the faculty. This can be accomplished in a morning.

The department is required to have the students fill out a university wide evaluation of the course at the end of the quarter. The staff member who administers the university evaluation also administers the outcome evaluation. The new form has added five minutes per course to the evaluation process. The outcome evaluations are given to the instructor after he or she has recorded the course grade.

The staff scans the completed course reports in order to maintain an electronic record of these reports. This process consumes about four hours a quarter of the staff time.

The total impact of the course report on the staff is one day for printing, copying, collating and scanning. The administering of the evaluation adds 2 hours per quarter to the current evaluation time.

Senior exit surveys

A staff member sends out an e-mail in the spring instructing the seniors to take the survey. The data collection, formatting and processing are done electronically.

The staff impact of the senior exit surveys is minimal.

Graduation pass surveys

The office of student life has been distributing this survey for many years. There is no impact on the engineering staff.

Summer survey

The staff copies these surveys for the faculty who administer them. The time required for copying is approximately half an hour.

One-year alumni survey

Since this survey is administered, collected and processed by the office of budget and planning, there is no impact on the staff of Mechanical engineering department

Three to five year alumni survey

The ME office staff copy the survey send it to the alumni and collect it. The total time required to accomplish this task is a day once every three years.

Proceedings of the 2002 American Society for Engineering Education Annual Conference \& Exposition

Copyright (C2002, American Society for Engineering Education 
Employer survey

This is administered through the College of Engineering office so it has minimal impact on the department resources.

The bulk of the work for the staff is concentrated on the course report. This process requires approximately one day a quarter.

Faculty workload.

Course report

The most time consuming aspect of the course report is averaging the student evaluations of the course outcomes. Even for large classes this averaging process takes at most an hour. Therefore completing the entire course report takes at most two hours per course. Typically a faculty member in ME only teaches one undergraduate course per quarter. This activity adds an additional two hours per quarter to the work load.

These course reports are read annually be the curriculum committee, which is divided into four sub committees. One for each of the main branches of the ME program at UCSB. The areas are thermal/fluids, dynamics and control, structure and materials, and environmental. A person from each group will read the course reports for the courses in each group and will report back to the curriculum committee. The total time to do this will vary by discipline and from year to year depending on the course offerings. It is estimated that it will take four hours to prepare each subdivision report for the committee.

The five remaining survey instruments contain a lot of information. Not all of which is need to assess the program objectives and outcomes. What will be described below is the time needed only to consider the part of the survey instruments, which directly assess the program outcomes and objectives. The material which is not reviewed by the ABET committee is available to other committees for institutional planning purposes.

Senior exit survey

Since this survey is processed electronically, it requires no work from the faculty to get the basic statistics for the graduating seniors. Only the results from three questions will be examined on an annual basis and included in the department ABET report. The work associated with analyzing these questions and including them in the annual ABET report to the department is approximately two hours.

Graduation pass survey.

Each department receives a two-page summary, which lists all of the employers, the salaries and the graduate schools and programs. This information is incorporated in the annual assessment report presented to the faculty.

Proceedings of the 2002 American Society for Engineering Education Annual Conference \& Exposition Copyright $@ 2002$, American Society for Engineering Education 
Summer Survey

Approximately 140 students return this survey annually. It takes one hour to compile the statistics from this form and an additional hour to write the section in the annual report related to this activity. The total work involved is two hours per year.

One-year alumni survey

The budget and planning office provides the faculty with the statistics for the College of Engineering alumni every other year. The ABET committee will review 13 questions, two with multiple parts. The analysis of this data takes approximately 4 hours to complete. It will be discussed by the ABET committee in the spring quarter and included in the annual report.

Three to five year alumni survey

Only six questions, one with multiple parts will be used for the assessment of the department outcomes and objectives. The work associated with compiling the statistics for these questions will depend on the number of alumni who respond. Since this survey is only administered every third year, the impact on the faculty workload should be minimal.

\section{Employer survey}

For the 2001-2002 academic year, the ME program has only received seven employer surveys back. The total time required to compute basic statistics for these surveys is one hour. To complete the section of the annual report relating to these forms is an additional hour. The employer survey has added two hours of work per year.

The assessment process of the outcomes and the objectives has increased the annual work of the faculty. The largest time is spent writing and analyzing the course reports. For each undergraduate course, a faculty member spends on average two hours producing the course report. Four members of the curriculum committee, spend an additional four hours per year reviewing these reports. The analysis of senior exit surveys, the summer surveys and the employer surveys add six hours of work for a faculty member. At the end of this paper, there is a time-line which shows when the data is collected, the various pieces are analyzed and the final report is written.

\section{Conclusion}

The assessment process described above is sustainable because the work has been distributed among the staff and the faculty. The total additional work for the staff amounts to approximately two days per quarter. The course report produces the most additional work for the faculty, which is two hours of work per quarter per faculty member and an additional six hours of work for four faculty members. This work is manageable if all of the faculty in the ME program participate in the process. 
ASSESSMENT TIME LINE WORK DONE EVERY YEAR

\begin{tabular}{|c|c|c|c|c|c|c|c|c|c|}
\hline & OCT & NOV & DEC & JAN & FEB & MAR & APR & MAY & JUN \\
\hline $\begin{array}{c}\text { Data } \\
\text { Collection }\end{array}$ & $\begin{array}{c}\text {-Summer } \\
\text { Survey }\end{array}$ & $\begin{array}{c}\text { •Employer } \\
\text { Survey } \\
\text { COE } \\
\text { Career Fair }\end{array}$ & $\begin{array}{l}\text {-Course } \\
\text { Reports } \\
\text { Collected }\end{array}$ & $\begin{array}{c}\text { •Employer } \\
\text { Survey } \\
\text { SWE }\end{array}$ & $\begin{array}{l}\bullet \text { IAB } \\
\text { Meets }\end{array}$ & $\begin{array}{l}\bullet \text { Course } \\
\text { Reports } \\
\text { Collected }\end{array}$ & $\begin{array}{l}\text { •Student } \\
\text { Focus } \\
\text { Groups }\end{array}$ & $\begin{array}{l}\text { •Senior } \\
\text { Exit } \\
\text { Survey }\end{array}$ & $\begin{array}{c}\text {-Graduation } \\
\text { Pass } \\
\text { •Course } \\
\text { Reports }\end{array}$ \\
\hline $\begin{array}{l}\text { Curriculum } \\
\text { Committee } \\
\text { Work }\end{array}$ & $\begin{array}{l}\text {-Analyze } \\
\text { course } \\
\text { reports } \\
\text { from } \\
\text { previous } \\
\text { academic } \\
\text { year }\end{array}$ & $\begin{array}{l}\bullet \text { Analyze all } \\
\text { survey data and } \\
\text { focus group } \\
\text { findings from } \\
\text { previous year }\end{array}$ & & & & $\begin{array}{l}\text {-Analyze } \\
\text { course } \\
\text { outcomes } \\
\text { grid } \\
\text {-Discuss } \\
\text { outcome } \\
\text { changes } \\
\text {-Produce } \\
\text { report } *\end{array}$ & & & \\
\hline $\begin{array}{l}\text { Faculty } \\
\text { Meeting }\end{array}$ & & $\begin{array}{l}\text { Divisions } \\
\text { meet to } \\
\text { discuss } \\
\text { course } \\
\text { reports } \\
\text { finding }\end{array}$ & $\begin{array}{l}\text { All } \\
\text { faculty } \\
\text { meeting- } \\
\text { discuss } \\
\text { course } \\
\text { report } \\
\text { finding }\end{array}$ & $\begin{array}{l}\text { All faculty } \\
\text { meeting- } \\
\text { discuss } \\
\text { survey } \\
\text { results }\end{array}$ & & & $\begin{array}{l}\text { All faculty } \\
\text { meeting - } \\
\text { present report } \\
\text { to faculty }\end{array}$ & & \\
\hline
\end{tabular}

\footnotetext{
* Assessment includes analysis of course reports, surveys and focus groups from previous year.
} 
MARIE DAHLEH received a B.A. degree in mathematics from Mount Holyoke College and M.A. and Ph.D. degrees in applied and computational mathematics from Princeton. She is now the academic coordinator for undergraduate affairs in the Mechanical engineering department at UCSB. She is coordin ating the UCSB College of Engineering preparation for the upcoming ABET accreditation visit. 